\title{
Psychroflexus salinarum sp. nov., isolated from a marine solar saltern
}

\author{
Jung-Hoon Yoon, So-Jung Kang, Yong-Taek Jung and Tae-Kwang Oh
}

Correspondence

Jung-Hoon Yoon

jhyoon@kribb.re.kr
Korea Research Institute of Bioscience and Biotechnology (KRIBB), PO Box 115, Yusong, Taejon, Republic of Korea

\begin{abstract}
A Gram-negative, non-motile and rod-shaped bacterial strain, ISL-14 ${ }^{\top}$, was isolated from a marine solar saltern of the Yellow Sea, Korea, and its taxonomic position was investigated by a polyphasic study. Strain ISL-14 ${ }^{\top}$ grew optimally at $\mathrm{pH} 7.0-8.0,30{ }^{\circ} \mathrm{C}$ and in the presence of approximately

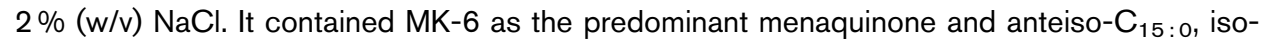
$\mathrm{C}_{15: 0}$ and iso- $\mathrm{C}_{16: 0} 3-\mathrm{OH}$ as the major fatty acids. The DNA G+C content was $38.5 \mathrm{~mol} \%$. A phylogenetic analysis based on 16S rRNA gene sequences showed that strain ISL-14 ${ }^{\top}$ belonged to the genus Psychroflexus. The levels of similarity between the 16S rRNA gene sequence of strain ISL-14 ${ }^{\top}$ and those of the type strains of recognized Psychroflexus species were 95.8$96.8 \%$. On the basis of phenotypic, chemotaxonomic and phylogenetic data, strain ISL-14 ${ }^{\top}$ represents a novel species within the genus Psychroflexus, for which the name Psychroflexus salinarum sp. nov. is proposed. The type strain is ISL-14 ${ }^{\top}\left(=\right.$ KCTC $22483^{\top}=$ CCUG $\left.56752^{\top}\right)$.
\end{abstract}

The genus Psychroflexus was proposed by Bowman et al. (1998) through the description of Psychroflexus torquis and the reclassification of Flavobacterium gondwanense as Psychroflexus gondwanensis. Subsequently, two more species of the genus, Psychroflexus tropicus (Donachie et al., 2004) and Psychroflexus sediminis (Chen et al., 2009), have been described. Phylogenetic analyses based on 16S rRNA gene sequences have shown that the genus Psychroflexus belongs to the family Flavobacteriaceae in the phylum Bacteroidetes (Bowman et al., 1998; Bernardet et al., 2002). In this study, we report on the taxonomic characterization of a Psychroflexus-like bacterial strain, ISL- $14^{\mathrm{T}}$, which was isolated from a marine solar saltern in Korea.

Strain ISL- $14^{\mathrm{T}}$ was isolated by means of the standard dilution plating technique at $30^{\circ} \mathrm{C}$ on marine agar 2216 (MA; Difco). P. gondwanensis DSM $5423^{\mathrm{T}}$ and P. tropicus DSM $15496^{\mathrm{T}}$, which were used as reference strains for fatty acid analysis, were obtained from the Deutsche Sammlung von Mikroorganismen und Zellkulturen (DSMZ), Braunschweig, Germany. The morphological, physiological and biochemical characteristics of strain ISL- $14^{\mathrm{T}}$ were investigated using routine cultivation on MA at $30{ }^{\circ} \mathrm{C}$. Cell morphology was examined by light microscopy (Nikon E600) and transmission electron microscopy. Flagellation was determined using a Philips CM-20 transmission electron microscope with cells from exponentially growing cultures: for this purpose, the cells were negatively stained with $1 \%(\mathrm{w} / \mathrm{v})$ phosphotungstic acid and the grids were examined after being air-dried. Gliding motility was

The GenBank/EMBL/DDBJ accession number for the 16S rRNA gene sequence of strain ISL-14 $4^{\top}$ is EU874390. investigated as described by Bowman (2000). Growth under anaerobic conditions was determined after incubation in a Forma anaerobic chamber on MA and on MA supplemented with potassium nitrate $(0.1 \%, \mathrm{w} / \mathrm{v})$, both of which had been prepared anaerobically under a nitrogen atmosphere. The $\mathrm{pH}$ range for growth was determined in marine broth 2216 (MB; Difco) that was adjusted to various $\mathrm{pH}$ values ( $\mathrm{pH} 4.5-9.5$ at intervals of $0.5 \mathrm{pH}$ units) by the addition of $\mathrm{HCl}$ or $\mathrm{Na}_{2} \mathrm{CO}_{3}$. Growth in the absence of $\mathrm{NaCl}$ was investigated using trypticase soy broth prepared according to the formula of the Difco medium except that $\mathrm{NaCl}$ was excluded. Growth at various $\mathrm{NaCl}$ concentrations $(0.5 \%, \mathrm{w} / \mathrm{v}$, and $1.0-20.0 \%$ at increments of $1.0 \%$ ) was investigated in $\mathrm{MB}$ or trypticase soy broth. Growth at various temperatures $(4,10,15,20,22,25,28$ and $30-40{ }^{\circ} \mathrm{C}$, at increments of $1{ }^{\circ} \mathrm{C}$ ) was measured on MA. Catalase and oxidase activities and hydrolysis of casein, starch and Tweens 20, 40,60 and 80 were determined as described by Cowan \& Steel (1965). DNase activity was examined by using DNase test agar with methyl green (Difco) supplemented with $2 \% \mathrm{NaCl}$. Hydrolysis of hypoxanthine, tyrosine and xanthine was tested on MA using the substrate concentrations described by Cowan \& Steel (1965). Hydrolysis of aesculin, gelatin and urea, and nitrate reduction were investigated as described by Lanyi (1987) with the modification that artificial sea water [(1 distilled water $)^{-1}: 23.6 \mathrm{~g} \mathrm{NaCl}, 0.64 \mathrm{~g}$ $\mathrm{KCl}, 4.53 \mathrm{~g} \mathrm{MgCl}_{2} \cdot 6 \mathrm{H}_{2} \mathrm{O}, 5.94 \mathrm{~g} \mathrm{MgSO}_{4} \cdot 7 \mathrm{H}_{2} \mathrm{O}, 1.3 \mathrm{~g}$ $\mathrm{CaCl}_{2} \cdot 2 \mathrm{H}_{2} \mathrm{O}$ (Bruns et al., 2001)] was used for preparation of the media. $\mathrm{H}_{2} \mathrm{~S}$ production was tested as described by Bruns et al. (2001). The presence of flexirubin type pigments was investigated as described by Reichenbach 
(1992). Susceptibility to antibiotics was investigated on MA plates by using antibiotic discs with the following amounts of antibiotic: polymyxin B (100 U); streptomycin $(50 \mu \mathrm{g})$, penicillin $\mathrm{G}(20 \mathrm{U})$, chloramphenicol $(100 \mu \mathrm{g})$, ampicillin $(10 \mu \mathrm{g})$, cephalothin $(30 \mu \mathrm{g})$, gentamicin $(30 \mu \mathrm{g})$, novobiocin $(5 \mu \mathrm{g})$, tetracycline $(30 \mu \mathrm{g})$, kanamycin $(30 \mu \mathrm{g})$, lincomycin $(15 \mu \mathrm{g})$, oleandomycin $(15 \mu \mathrm{g})$, neomycin $(30 \mu \mathrm{g})$ and carbenicillin $(100 \mu \mathrm{g})$. Acid production from carbohydrates was tested as described by Leifson (1963). Enzyme activities were determined by using the API ZYM system (bioMérieux).

Cell biomass for DNA extraction and for isoprenoid quinone analysis was obtained from cultures grown in $\mathrm{MB}$ at $30^{\circ} \mathrm{C}$. Chromosomal DNA was isolated and purified according to the method described by Yoon et al. (1996), with the exception that RNase $\mathrm{T} 1$ was used in combination with RNase A to minimize the contamination of RNA. The $16 \mathrm{~S}$ rRNA gene was amplified by PCR using two universal primers as described previously (Yoon et al., 1998). Sequencing of the amplified $16 \mathrm{~S}$ rRNA gene and phylogenetic analysis were performed as described by Yoon et al. (2003). Isoprenoid quinones were analysed as described by Komagata \& Suzuki (1987) using reversed-phase HPLC. For cellular fatty acid analysis, cell mass of strain ISL- $14^{\mathrm{T}}$ was harvested from MA plates after cultivation for 3 days at $30{ }^{\circ} \mathrm{C}$. The fatty acids were extracted and fatty acid methyl esters were prepared according to the standard protocol of the MIDI/Hewlett Packard Microbial Identification System (Sasser, 1990). The DNA G + C content was determined by the method of Tamaoka \& Komagata (1984) with a modification that DNA

\section{Table 1. Differential phenotypic characteristics of Psychroflexus species}

Species: 1, P. salinarum ISL-14 ${ }^{\mathrm{T}}$; 2, P. torquis ACAM 623 ${ }^{\mathrm{T}}$ (Bowman et al., 1998; Donachie et al., 2004); 3, P. gondwanensis ACAM $48^{\mathrm{T}}$ (Bowman et al., 1998; Donachie et al., 2004); 4, P. tropicus LA1 ${ }^{\mathrm{T}}$ (Donachie et al., 2004); 5, P. sediminis YIM-C238 ${ }^{\mathrm{T}}$ (Chen et al., 2009). +, Positive reaction; -, negative reaction; $w$, weakly positive reaction; ND, not detected. All species are positive for activities of catalase and alkaline phosphatase. All species are negative for acid production from cellobiose and rhamnose, and for activities of $\alpha$-galactosidase, $\beta$-galactosidase, $\alpha$-fucosidase and $\alpha$ mannosidase.

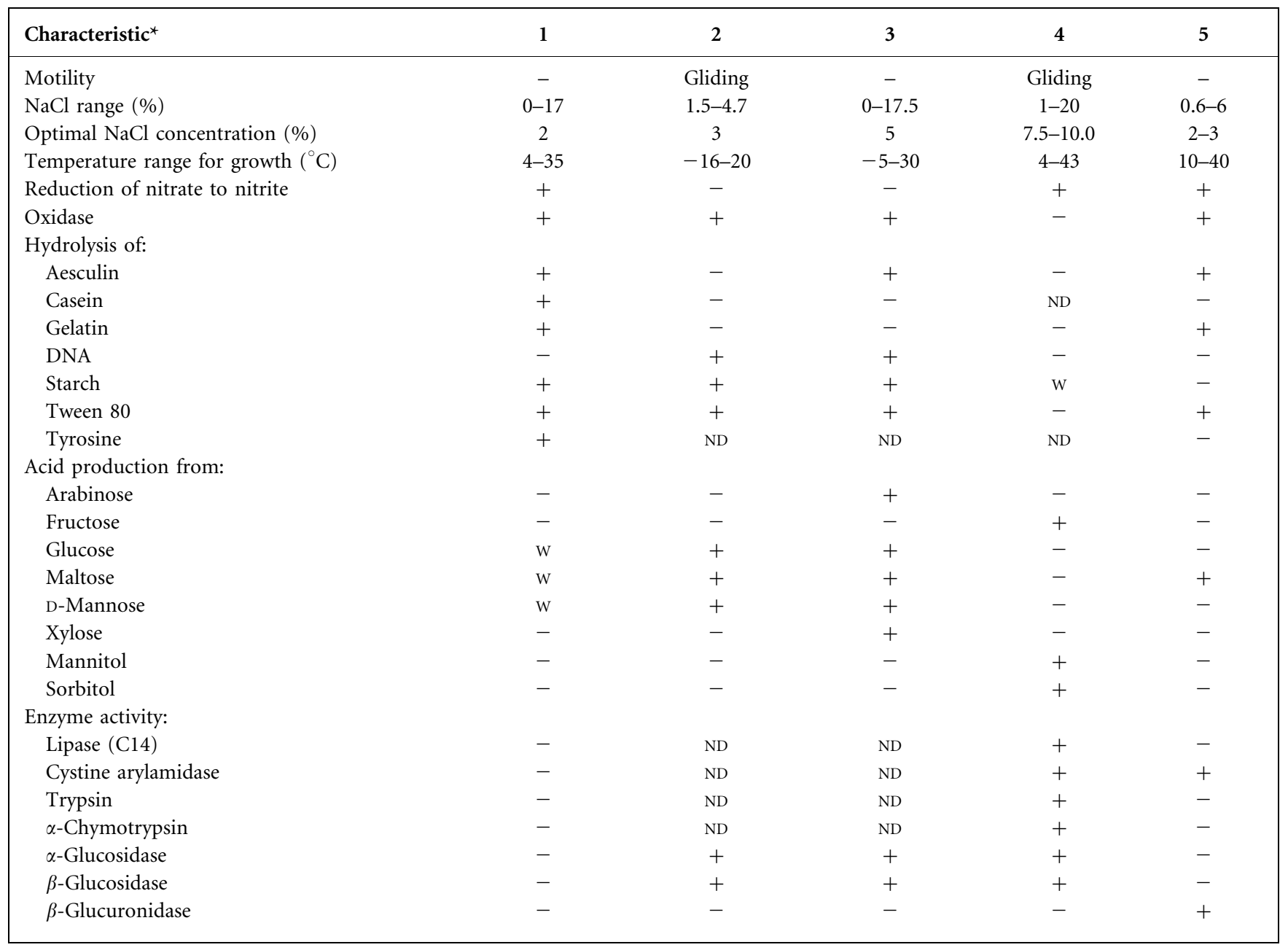


was hydrolysed using nuclease P1 (Sigma) and the resultant nucleotides were analysed by reversed-phase HPLC.

Morphological, cultural, physiological and biochemical characteristics of strain ISL- $14^{\mathrm{T}}$ are given in the species description (see below) or are shown in Table 1. The almostcomplete 16S rRNA gene sequence of strain ISL-14 ${ }^{\mathrm{T}}$ determined in this study comprised $1446 \mathrm{nt}$, representing approximately $96 \%$ of the Escherichia coli $16 \mathrm{~S}$ rRNA gene sequence. In the phylogenetic tree based on the neighbourjoining algorithm, strain ISL- $14^{\mathrm{T}}$ joined the cluster containing the type strains of Psychroflexus species with a bootstrap resampling value of $100 \%$ (Fig. 1). The clustering of strain ISL-14 ${ }^{\mathrm{T}}$ with the four recognized Psychroflexus species was also observed in the trees constructed using the maximumlikelihood and maximum-parsimony algorithms (Fig. 1). Strain ISL- $14^{\mathrm{T}}$ exhibited $16 \mathrm{~S}$ rRNA gene sequence similarity values of $95.8-96.8 \%$ to the type strains of the four recognized Psychroflexus species and less than $93.2 \%$ to other species used in the phylogenetic analysis.

The predominant menaquinone detected in strain ISL- $14^{\mathrm{T}}$ was MK-6 (at a peak area ratio of approximately $96 \%$ ). The cellular fatty acid profile of strain ISL- $14^{\mathrm{T}}$ is shown in Table 2, together with those of two Psychroflexus species analysed in this study. Strain ISL-1 $4^{\mathrm{T}}$ had large amounts of branched and hydroxy fatty acids; the major components $\left(>10 \%\right.$ of total fatty acids) were anteiso- $C_{15: 0}$, iso- $C_{15: 0}$ and iso- $\mathrm{C}_{16: 0} 3-\mathrm{OH}$. This fatty acid profile was similar to those of $P$. torques, $P$. gondwanensis and $P$. sediminis, but different from that of $P$. tropicus in the proportions of some fatty acids, particularly iso- $\mathrm{C}_{15: 1}$, iso- $\mathrm{C}_{15: 0}$, anteiso$\mathrm{C}_{15: 0}$ and iso- $\mathrm{C}_{16: 0} 3-\mathrm{OH}$ (Donachie et al., 2004; Table 2). The DNA G $+\mathrm{C}$ content of strain ISL- $14^{\mathrm{T}}$ was $38.5 \mathrm{~mol} \%$. The results obtained from these chemotaxonomic analyses supported the result of the phylogenetic analysis, suggesting that strain ISL- $14^{\mathrm{T}}$ belongs to the genus Psychroflexus.

Strain ISL-14 ${ }^{\mathrm{T}}$ was distinguishable from other recognized Psychroflexus species by differences in several phenotypic characteristics as listed in Table 1 . The phylogenetic distinctiveness and differential phenotypic properties of strain ISL-14 ${ }^{\mathrm{T}}$ are sufficient to suggest that this strain is separate from the four recognized Psychroflexus species (Stackebrandt \& Goebel, 1994). On the basis of the data presented, strain ISL-14 ${ }^{\mathrm{T}}$ represents a novel species of the genus Psychroflexus, for which the name Psychroflexus salinarum sp. nov. is proposed.

\section{Description of Psychroflexus salinarum sp. nov.}

Psychroflexus salinarum (sa.li.na'rum. L. pl. gen. n. salinarum of salterns).

Cells are Gram-negative rods, $0.2-0.4 \mu \mathrm{m}$ in diameter and $0.8-8.0 \mu \mathrm{m}$ in length. Cells longer than $10.0 \mu \mathrm{m}$ occasionally occur. Non-motile. Colonies on MA are circular, slightly convex, glistening, smooth, dark orange in colour and $1.5-2.0 \mathrm{~mm}$ in diameter after 3 days incubation at $30{ }^{\circ} \mathrm{C}$. Growth occurs at 4 and $35{ }^{\circ} \mathrm{C}$, but not at $36{ }^{\circ} \mathrm{C}$. Optimal $\mathrm{pH}$ for growth is between 7.0 and 8.0; growth occurs at $\mathrm{pH}$ 6.0, but not at $\mathrm{pH}$ 5.5. Growth occurs in the presence of $17 \%(\mathrm{w} / \mathrm{v}) \mathrm{NaCl}$, but not in the absence of $\mathrm{NaCl}$ or in the presence of more than $18 \%(\mathrm{w} / \mathrm{v}) \mathrm{NaCl}$. Anaerobic growth does not occur on MA or on MA supplemented with nitrate. $\mathrm{H}_{2} \mathrm{~S}$ is not produced. Flexirubin-type pigments are not produced. Tweens 20, 40 and 60 are hydrolysed, but hypoxanthine and xanthine are not. Acid is not produced from galactose, lactose, melezitose, melibiose, raffinose, ribose, sucrose, trehalose and myo-inositol. In assays with the API ZYM system, esterase (C4), esterase lipase (C8), leucine arylamidase, valine arylamidase, acid phosphatase and naphthol-AS-BIphosphohydrolase are present, but $\mathrm{N}$-acetyl- $\beta$-glucosaminidase is absent. Susceptible to ampicillin, carbenicillin, cephalothin, chloramphenicol, lincomycin, novobiocin, oleandomycin, penicillin $\mathrm{G}$ and tetracycline, but not to gentamicin, kanamycin, neomycin, polymyxin $\mathrm{B}$ and streptomycin. The predominant menaquinone is MK-6. The major fatty acids ( $>10 \%$ of total fatty acids) are

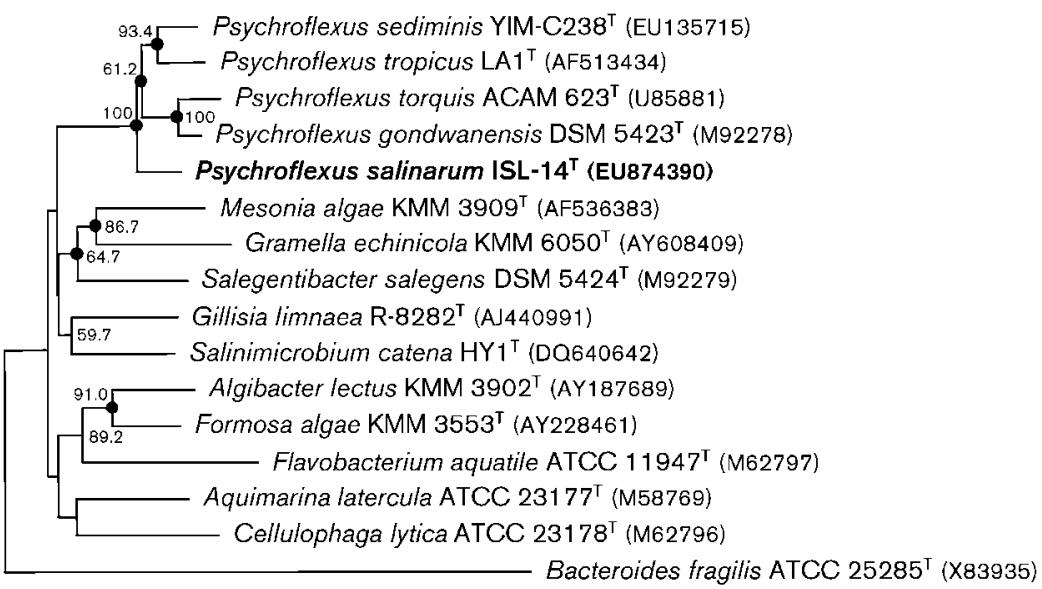

0.05

\begin{abstract}
Fig. 1. Neighbour-joining phylogenetic tree based on 16S rRNA gene sequences showing the positions of Psychroflexus salinarum ISL-14 ${ }^{\top}$, Psychroflexus species and some other related taxa. Bootstrap values (expressed as percentages of 1000 replications) of $>50 \%$ are shown at branch points. Filled circles indicate that the corresponding nodes were also recovered in the trees generated with the maximum-likelihood and maximum-parsimony algorithms. Bacteroides fragilis ATCC $25285^{\top}$ was used as an outgroup. Bar, 0.05 substitutions per nucleotide position.
\end{abstract}


Table 2. Cellular fatty acid composition (\%) of $P$. salinarum ISL-14 ${ }^{\top}$ and the type strains of four Psychroflexus species

Strain: 1 , P. salinarum ISL- $14^{\mathrm{T}} ; 2, P$. gondwanensis DSM $5423^{\mathrm{T}}$ (this study); 3, P. tropicus DSM $15496^{\mathrm{T}}$ (this study); 4, P. sediminis YIM-C238 ${ }^{\mathrm{T}}$ (Chen et al., 2009); 5, P. torquis ACAM $623^{\mathrm{T}}$ (Bowman et al., 1998). Fatty acids that represented $<0.5 \%$ in all strains were omitted. -, Not detected.

\begin{tabular}{|c|c|c|c|c|c|}
\hline Fatty acid & 1 & 2 & 3 & 4 & 5 \\
\hline \multicolumn{6}{|c|}{ Straight-chain fatty acids } \\
\hline $\mathrm{C}_{15: 0}$ & 1.3 & 1.5 & 6.0 & - & 4.2 \\
\hline $\mathrm{C}_{16: 0}$ & 0.2 & 0.2 & 0.3 & - & 0.6 \\
\hline \multicolumn{6}{|l|}{ Unsaturated fatty acids } \\
\hline $\mathrm{C}_{16: 1}$ & - & - & - & $3.2^{*}$ & - \\
\hline $\mathrm{C}_{17: 1} \omega 6 c$ & 1.0 & - & - & 1.8 & - \\
\hline $\mathrm{C}_{20: 4} \omega 6 c$ & - & - & - & - & 2.1 \\
\hline $\mathrm{C}_{20: 5} \omega 3 c$ & - & - & - & - & 4.9 \\
\hline \multicolumn{6}{|l|}{ Branched fatty acids } \\
\hline iso- $\mathrm{C}_{13: 0}$ & 1.5 & - & 0.9 & 0.4 & 0.7 \\
\hline anteiso- $\mathrm{C}_{13: 0}$ & 0.4 & 0.5 & - & 2.8 & - \\
\hline iso- $\mathrm{C}_{14: 0}$ & 7.1 & 6.5 & 1.4 & 7.8 & 1.0 \\
\hline iso- $\mathrm{C}_{15: 1}$ & 2.3 & 0.7 & 12.9 & 2.7 & 0.4 \\
\hline anteiso- $\mathrm{C}_{15: 1}$ & 4.0 & 10.9 & 0.7 & 10.7 & 16.9 \\
\hline iso- $\mathrm{C}_{15: 0}$ & 17.9 & 1.8 & 41.6 & 1.6 & 1.1 \\
\hline anteiso- $\mathrm{C}_{15: 0}$ & 23.7 & 33.2 & 3.4 & 29.4 & 35.2 \\
\hline iso- $\mathrm{C}_{16: 0}$ & 7.6 & 7.0 & 0.8 & 1.9 & 6.0 \\
\hline \multicolumn{6}{|l|}{ Hydroxy fatty acids } \\
\hline iso- $\mathrm{C}_{14: 0} 3-\mathrm{OH}$ & 1.1 & 1.0 & 0.3 & 1.1 & - \\
\hline iso- $\mathrm{C}_{15: 0} 3-\mathrm{OH}$ & 2.0 & - & 5.6 & 1.4 & 0.3 \\
\hline $\mathrm{C}_{15: 0} 2-\mathrm{OH}$ & 3.0 & 4.6 & 0.5 & 4.8 & - \\
\hline $\mathrm{C}_{15: 0} 3-\mathrm{OH}$ & 0.2 & 0.4 & 2.7 & 1.0 & 2.5 \\
\hline iso- $\mathrm{C}_{16: 0} 3-\mathrm{OH}$ & 12.2 & 19.4 & 2.2 & 16.1 & 15.4 \\
\hline $\mathrm{C}_{16: 0} 3-\mathrm{OH}$ & 0.2 & 0.5 & 1.7 & - & 1.2 \\
\hline iso- $\mathrm{C}_{17: 0} 3-\mathrm{OH}$ & 6.3 & 1.2 & 12.9 & 4.2 & 0.2 \\
\hline anteiso- $\mathrm{C}_{17: 0} 3-\mathrm{OH}$ & - & - & - & - & 10.9 \\
\hline $\mathrm{C}_{17: 0} 2-\mathrm{OH}$ & 3.7 & 9.1 & 0.6 & 6.7 & - \\
\hline Summed feature $3 \dagger$ & 2.0 & - & 1.2 & - & - \\
\hline \multicolumn{6}{|l|}{ Unknown fatty acids } \\
\hline ECL 13.565 & 0.8 & 0.1 & 1.2 & - & - \\
\hline ECL 16.582 & 0.6 & - & 1.1 & - & - \\
\hline
\end{tabular}

${ }^{\star}$ Double bond positions in $C_{16: 1}$ were either $\omega 6 c$ or $\omega 7 c$.

${ }^{\dagger}$ Summed features represent groups of two or three fatty acids which cannot be separated by GLC with the MIDI system. Summed feature 3 contains $\mathrm{C}_{16: 1} \omega 7 c$ and/or iso- $\mathrm{C}_{15: 0} 2-\mathrm{OH}$.

anteiso- $\mathrm{C}_{15: 0}$, iso- $\mathrm{C}_{15: 0}$ and iso- $\mathrm{C}_{16: 0}$ 3-OH. The DNA $\mathrm{G}+\mathrm{C}$ content is $38.5 \mathrm{~mol} \%$ (determined by HPLC). Other phenotypic characteristics are given in Table 1.

The type strain, ISL- $14^{\mathrm{T}} \quad\left(=\right.$ KCTC $\quad 22483^{\mathrm{T}}=\mathrm{CCUG}$ $\left.56752^{\mathrm{T}}\right)$, was isolated from a marine solar saltern from the Yellow Sea, Korea.

\section{Acknowledgements}

This work was supported by the 21C Frontier program of Microbial Genomics and Applications (grant MG05-0401-2-0) from the
Ministry of Science and Technology (MOST) of the Republic of Korea.

\section{References}

Bernardet, J.-F., Nakagawa, Y. \& Holmes, B. (2002). Proposed minimal standards for describing new taxa of the family Flavobacteriaceae and emended description of the family. Int J Syst Evol Microbiol 52, 1049-1070.

Bowman, J. P. (2000). Description of Cellulophaga algicola sp. nov., isolated from the surfaces of Antarctic algae, and reclassification of Cytophaga uliginosa (ZoBell and Upham 1944) Reichenbach 1989 as Cellulophaga uliginosa comb. nov. Int J Syst Evol Microbiol 50, 1861-1868.

Bowman, J. P., McCammon, S. A., Lewis, T., Skerratt, J. H., Brown, J. L., Nichols, D. S. \& McMeekin, T. A. (1998). Psychroflexus torquis gen. nov., sp. nov., a psychrophilic species from Antarctic sea ice, and reclassification of Flavobacterium gondwanense (Dobson et al. 1993) as Psychroflexus gondwanense gen. nov., comb. nov. Microbiology 144, 1601-1609.

Bruns, A., Rohde, M. \& Berthe-Corti, L. (2001). Muricauda ruestringensis gen. nov., sp. nov., a facultatively anaerobic, appendaged bacterium from German North Sea intertidal sediment. Int $J$ Syst Evol Microbiol 51, 1997-2006.

Chen, Y.-G., Cui, X.-L., Wang, Y.-X., Tang, S.-K., Zhang, Y.-Q., Li, W.-J., Liu, J.-H., Peng, Q. \& Xu, L.-H. (2009). Psychroflexus sediminis sp. nov., a mesophilic bacterium isolated from salt lake sediment in China. Int J Syst Evol Microbiol 59, 569-573.

Cowan, S. T. \& Steel, K. J. (1965). Manual for the Identification of Medical Bacteria. London: Cambridge University Press.

Donachie, S. P., Bowman, J. P. \& Alam, M. (2004). Psychroflexus tropicus sp. nov., an obligately halophilic Cytophaga-FlavobacteriumBacteroides group bacterium from an Hawaiian hypersaline lake. Int $J$ Syst Evol Microbiol 54, 935-940.

Komagata, K. \& Suzuki, K. (1987). Lipids and cell-wall analysis in bacterial systematics. Methods Microbiol 19, 161-207.

Lanyi, B. (1987). Classical and rapid identification methods for medically important bacteria. Methods Microbiol 19, 1-67.

Leifson, E. (1963). Determination of carbohydrate metabolism of marine bacteria. J Bacteriol 85, 1183-1184.

Reichenbach, H. (1992). The order Cytophagales. In The Prokaryotes. A Handbook on the Biology of Bacteria: Ecophysiology, Isolation, Identification, Applications, 2nd edn, pp. 3631-3675. Edited by A. Balows, H. G. Trüper, M. Dworkin, W. Harder \& K. H. Schleifer. New York: Springer.

Sasser, M. (1990). Identification of Bacteria by Gas Chromatography of Cellular Fatty Acids, Technical Note No. 1. Newark, DE: MIDI.

Stackebrandt, E. \& Goebel, B. M. (1994). Taxonomic note: a place for DNA-DNA reassociation and 16S rRNA sequence analysis in the present species definition in bacteriology. Int J Syst Bacteriol 44, 846-849.

Tamaoka, J. \& Komagata, K. (1984). Determination of DNA base composition by reverse-phase high-performance liquid chromatography. FEMS Microbiol Lett 25, 125-128.

Yoon, J.-H., Kim, H., Kim, S.-B., Kim, H.-J., Kim, W. Y., Lee, S. T., Goodfellow, M. \& Park, Y.-H. (1996). Identification of Saccharomonospora strains by the use of genomic DNA fragments and rRNA gene probes. Int J Syst Bacteriol 46, 502-505.

Yoon, J.-H., Lee, S. T. \& Park, Y.-H. (1998). Inter- and intraspecific phylogenetic analysis of the genus Nocardioides and related taxa based on 16S rRNA gene sequences. Int J Syst Bacteriol 48, 187-194.

Yoon, J.-H., Kang, K. H. \& Park, Y.-H. (2003). Psychrobacter jeotgali sp. nov., isolated from jeotgal, a traditional Korean fermented seafood. Int J Syst Evol Microbiol 53, 449-454. 